\title{
KOMUNIKASI MASSA DALAM PELAKSANAAN PROGRAM SIARAN RADIO (Analisis Tanggung Jawab Sosial Pelaksanaan Program Siaran Coffee Morning di Programa 2 LPP RRI Bengkulu)
}

Oleh:

\author{
DETE KONGGORO, DWI KUSUMA YUNIARTI, MARYANINGSIH \\ Program Studi Ilmu Komunikasi Fakultas Ilmu-Ilmu Sosial UNIVED Bengkulu
}

\begin{abstract}
This study aimed to investigate the implementation of social responsibility in a broadcasting program Coffee Morning in programa 2 LPP RRI Bengkulu. This study used qualitative method, where the informants in this study was the Head of Press LPP RRI Bengkulu, Kasubsi Programa 2 LPP RRI, Stage Manager, Presenter, Presenter dialogue. Primary data in this study was obtained from interview to the informants, and secondary data obtained through library research. This study found that the implementation of social responsibility in a broadcasting program Coffee Morning in Programa 2 RRI Bengkulu LPP has been carried out based on the legal framework and institutions, meet the high standards of professionalism and information, correctness, accuracy, objectivity and balance, avoiding anything that might induce crime, detriment, public disorder or insult against ethnic or religious minorities, seeks to reflect the plurality and diversity of society, set high achievement standards, and intervention can be justified to safeguard the public interest. In other words, the implementation of this program fulfills a social responsibility towards the community listeners.
\end{abstract}

Keywords: Broadcasting, Radio, Social Responsibility, Indonesia National Radio Station Programa 2

\section{PENDAHULUAN}

Mempelajari komunikasi elektronik, seperti Televisi, Radio, Internet merupakan hal yang sangat diperlukan dalam hal untuk mendapatkan informasi yang kita butuhkan dewasa ini. Radio adalah salah satu yang terpenting. Di masa sekarang ini dengan kita mudah dapat menikmati penyiaran radio dan telinga kita dimanjakan melalui bunyi-bunyian dan suara. Kemajuan teknologi juga memungkinkan fitur FM radio di telepon seluler yang memungkinkan kita untuk mendapatkan berbagai informasi dan hiburan dari radio dimana pun dan kapan pun.Hal itu membuat radio semakin dekat dengan manusia, yangsecara tidak langsung membentuk kebiasaan sosial melalui informasi, berita dan hiburan yang disajikan baik oleh reporter lapangan maupun oleh penyiarnya.

Radio merupakan salah satu media komunikasi lisan, karenanya penting bagi penyiar untuk profesional. Penyiar harus mampu menyampaikan pesan atau berita lebih efektif dari pada dikomunikasikan melalui kata-kata yang tertulis. Komunikasi lisan tidak akan efektif apabila penyiar radio gagal menyampaikan materi dengan jelas serta meyakinkan. Seiring dengan perkembangan teknologi dan kemajuan zaman, peran dan fungsi radio masa telah berubah, selain lebih bersifat komersil peminat/pendengar radio pun berkembang. Perkembangan program yang disajikan tiaptiap stasiun radio pun semakin beragam. 
Radio merupakan salah satu media komunikasi massa. Sama seperti media komunikasi massa lainnya, radio memiliki beberapa fungsi yaitu sebagai alat penerangan, pendidikan, mempengaruhi massa, dan hiburan. Pendengar radio mencakup orang-orang dari berbagai jenis pekerjaan, usia, budaya, tempat, dan kondisi sosial ekonomi yang berbeda. Perhatian mereka terfokus pada hal yang sama yaitu berita atau acara yang disajikan. Radio bersifat publik dan heterogen dimana isinya terbuka bagi semua orang.

Radio Republik Indonesia (RRI) yang merupakan radio pemerintah memiliki fungsi sebagai sebagai lembaga penyiaran publik tidak hanya memberikan informasi yang aktual, tepat dan terpercaya, namun juga memberikan nilai-nilai edukatif seperti memberikan porsi pada siaran pendidikan, baik secara instruksional seperti siaran SLTP, SMU dan universitas, juga memberikan pendidikan masyarakat seperti siaran pedesaan, siaran wanita, siaran nelayan, dll. Tidak ketinggalan, RRI juga menyediakan siaran yang menyajikan nilai seni dan budaya bangsa yang dikemas dengan menarik.Hiburan musik dari manca negara pun tersaji apik dalam siaran RRI.Luas area jangkauan siaran RRI tidak saja di dalam negeri namun juga menembus sampai mancanegara yang tersaji dalam Voice of Indonesia yang merupakan siaran khusus luar negri.

Secara jelas, Programa Dua LPP RRI Bengkulu belum menyatakan jika dalam pelaksanaan program siaran Coffee Morning sudah sejalan dengan tanggung jawab sosial media.Oleh karena itu, penulis tertarik melakukan penelitian terhadap pelaksanaan program Coffee Morning Pro 2 RRI Bengkulu tersebut dengan mengangkat judul "Komunikasi dalam Pelaksanaan Program Siaran Radio (Analisis Tanggung Jawab Sosial Pelaksanaan Program Coffee Morningdi Programa Dua LPP RRI Bengkulu)“

\section{METODOLOGI PENELITIAN}

Pendekatan yang digunakan dalam penelitian ini adalah pendekatan kualitatif. Data dalam penelitian ini dibedakan menjadi dua, yaitu data primer yang diperoleh lansung dari lapangan atau tempat penelitian yang dilakukan dengan pengamatan (observasi) dan wawancara, dan data sekunder yang yang didapat dari sumber bacaan dan berbagai macam sumber lainnya. Adapun wawancara dilakukan terhadap para pejabat struktural dan para penyiar program siaran Coffee Morning Programa 2 LPP RRI Bengkulu, yaitu:

1. Kasi Siaran LPP RRI Bengkulu selaku Produser

1. Kasubsi Programa 2 LPP RRI Bengkulu selaku Sutradara

2. Pengarah Acara selaku orang yang bertanggung jawab atas konsep, format dan konten acara

3. Stage Manager, selaku orang yang bertanggung jawab atas pelaksanaan program di lapangan

4. Presenter acara hiburan dan presenter acara dialog, selaku orang yang bertanggung jawab atas jalannya acara hiburan dan dialog.

Penelitian mengambil lokasi di LPP RRI Bengkulu di Jl. S.Parman no 31 Bengkulu.LPP RRI Bengkulu merupakan satu-satunya radio pemerintah yang ada di Provinsi Bengkulu.

Setelah data dari lapangan terkumpul, peneliti mengolah dan menganalisis data tersebut dengan menggunakan analisis secara deskriptifkualitatif. Teknik analisis data yang digunakan dalam penelitian ini mengacu pada langkah-langkah yang dikemukakan Burhan Bungin (2003:70), yaitu: pengumpulan data (Data Collection), reduksi data (proses pemilihan, pemusatan perhatian pada penyederhanaan dan transformasi data kasar yang muncul dari catatan tertulis di lapangan), display data, dan verifikasi dan penegasan kesimpulan (conclution drawing and verification). 
Keabsahan data dalam penelitian ini dilakukan dengan triangulasi. Adapun triangulasi adalah teknik pemeriksaan keabsahan data yang memanfaatkan sesuatu yang lain di luar data itu untuk keperluan pengecekan atau sebagai pembanding terhadap data itu (Moleong, 2007: 330). Dalam memenuhi keabsahan data penelitian ini dilakukan triangulasi dengan sumber. Menurut Patton, triangulasi dengan sumber berarti membandingkan dan mengecek balik derajat kepercayaan suatu informasi yang diperoleh melalui waktu dan alat yang berbeda dalam penelitian kualitatif (Moleong, 2007: 29).

\section{HASIL DAN PEMBAHASAN Hasil Penelitian}

Di RRI Bengkulu terdapat 3 programa yang mengudara, Pro 1, Pro 2, dan Pro 3. Programa 2 (Pro2) mulai tahun 2011 lebih diarahkan dan fokus memenuhi kebutuhan pendengar sebagai Pusat Kreativitas Anak Muda.Melalui siaransiarannya, Pro2 harus menjadi referensi pembentukan karakter anak muda Indonesia.

Pro2 menjadikan musik sebagai sumber utama hiburan dengan tetap menyajikan informasi yang meningkatkan kecerdasan dan kreativitas anak muda. Secara umum informasi adalah data tentang apa saja yang sudah diolah menjadi suatu pesan yang dapat diterima dan dipahami pendengar sebagai ilmu pengetahuan yang berguna, baik masa sekarang atau yang akan datang.

Hiburan dalam program radio adalah segala sesuatu yang berbentuk katakata, gambaran sebuah tempat, benda, perilaku yang dapat menjadi penghibur atau pelipur hati yang sedih, pada umumnya hiburan dapat berupa musik, nada dan irama yang dihasilkan alat atau suara yang didengar dan dinikmati semua orang, juga drama radio, obrolan komedi, quiz, bahkan informasi tentang olah raga. Dengan demikian, dalam format Pro2 jelas terdapat bauran antara informasi dan hiburan. Disamping dalam bentuk on air, juga dimungkinkan melakukan kegiatan off airsepanjang konsisten dengan format stasiun.Tujuan akhirnya, anak muda berperilaku sesuai dengan pengetahuan yang dimiliki (knowledge based society).

Pro 2 memposisikan diri sebagai radio siaran tempat proses konstruksi ide orisinilyang melahirkan sesuatu yang baru, baik gagasan maupun karya nyata, yang berbedadengan karya sebelumnya. Kreativitas muncul dari interaksi pribadi dengan lingkungandan pengetahuan. Pro 2 sebagai ruang kreativitas anak muda, membuka partisipasidalam olah programming kepada anak muda dan merupakan perwujudan pelayananparipurna RRI, baik on air maupun off air

\section{- Sasaran Khalayak}

Berdasarkan buku

Pedoman Penyelenggaraan Siaran Programa Satu dan Dua (RRI, 2011) pasal 9 disebutkan bahwa pendengar Pro 2 adalah orang muda yang telah berusia 12-25 tahun, laki-laki dan perempuan berstatus sosial ekonomi B-C. Strata Ekonomi Sosial (SES), ialah pengelompokan masyarakat berdasarkan pengeluaran (expenditure) biaya hidup suatu keluarga rata-rata dalam 1 (satu) bulan, yang dikategorikan menjadi :

a. Rata-rata Rp. 5 juta ke atas/bulan

b. Rata-rata antara Rp. 3 hingga Rp. 5 juta/bulan

c. Rata-rata antara Rp. 2 hingga Rp. 3 juta/bulan

d. Rata-rata antara Rp. 1 hingga Rp. 2 juta/bulan

e. Rata-rata Rp. 1 juta ke bawah/bulan.

Lebih lanjut, berdasarkan buku Pedoman Penyelenggaraan Siaran Programa Satu dan Dua (RRI, 2011) gambaran psikologi pendengar Pro 2 berdasarkan strata ekonomi sosial $(B, C)$ adalah remaja yang diyakini selalu menginginkan perubahan, meningkat dalam pendidikan dan pengetahuan, mengikuti perkembangan teknologi, budaya popular dan gaya hidup, 
selalu ingin tahu lebih banyak tentang berbagai hal. Pro 2 melalui siarannya diharapkan dapat ikut mencari jalan keluar menuntaskan berbagai permasalahan anak muda kontemporer yang disebabkan proses pendewasaan, sumbatan komunikasi, faktor sosial internal dan eksternal melalui penyampaian informasi harus memuat pesan-pesan sesuai nilai dan norma budaya Indonesia, disampaikan secara komunikatif dengan dialek dan lambang verbal yang disukai anak muda, dengan tetap memperhatikan bahasa yang baik dan benar, yaitu:

1. Mengajak anak muda Indonesia "mendengarkan-memperhatikan"

motivasi dari keluarga, guru, teman sebaya untuk melakukan tindakan positif dalam bentuk prestasi di dunia seni budaya, keilmuan, olah raga. Contoh program-program yang menunjang fungsi ini antara lain Program Pro Sport yang menyajikan informasi dana hal-hal yangberhubungan dengan dunia olahraga, Program Kreasi Seni dan Budaya yang merupakan wadah penyaluran bakal seni dan budaya, Program-program Talk Show psikologis, keagamanaan dan sebagainya untuk memberikan perluasan wawasan bagi pendengar.

2. Mengajak pendengar anak muda berpartisipasi membantu keluarga membenahi kondisi ekonomi sehingga tercipta keluarga yang harmonis, komunikatif, dan nyaman bagi remaja dan anggota keluarga lainnya. Untuk menjalankan fungsi ini Pro 2 RRI Bengkulu, Program Obrolan Bersama Sahabat Inspiratif yang menghadirkan dialog interaktif bersama orang muda yang kreatif dan berprestasi, pengusaha muda, dsb.

3. Memberi tips memilih teman dan lingkungan, memberi arahan dengan siapa dan di komunitas mana remaja harus bergaul, mengajak membentuk ketahanan diri agar tidak mudah terpengaruh jika ternyata teman sebaya atau komunitas yang ada berperilaku tidak terpuji. Contoh program untuk membina psikologis remaja pendengar Pro 2 adalah program Pro Psikologis dalam bentuk dialog interaktif bersama Psikolog.

4. Mengajak anak muda lebih mawas diri, memilih tontonan yang bermanfaat, terhadap program acara dan televisi, rubrik dalam media cetak, mengunduh tautan pornografi pada internet, dll. Contoh program dalam menjalankan fungsi ini, Pro 2 Bengkulu menghadirkan program Qalbu Plus, sebuah program pembinaan dan pendidikan keagamaan.

5. Mengajak anak muda mengikuti kegiatan ekstra kurikuler dan pengembangan diri di sekolah, karena disanalah tempat untuk lebih banyak menghabiskan waktu selain di rumah, seperti program PRO INDI, yang menjadi wadah penyaluran bakat bermusik.

6. Mendorong anak muda menekuni hobi kreatif yang mereka sukai dan menggunakan kesempatan mengembangkan bakat untuk pengembangan diri. Pro 2 RRI Bengkulu menghadirkan program PRO \& COM yang menjadi wadah anak muda dan komunitas serta hobinya.

Program ini dilaksanakan secara off air-on air, artinya program dilaksanakan secara off air langsung berlokasi di sekolah/kampus yang dipilih terlebih dahulu melalui survei dan pengamatan cermat,dan disiarkan secara langsung melalui Pro 2, sebagaimana dikatakan Rizki Nopita Handayani Hasan sebagai Pengarah Acara Program Coffee Morning:

"Iya... jadi mas... program ini kita padukan on air-off air, maksudnya. Kita siarannya live dari lokasi sekolah ato kampus yang kita pilih kan yah, acara ini berlangsung secara off air dan disiarkan secara live di Pro 2. Untuk 
penentuan lokasinya, kita bener-bener selective, kita pelajari dengan baik letaknya, cocok nggaknya, bisa ato enggak kalo kita adakan siaran langsung dari sana, ada tempatnya ato enggak, semua semua deh kita pelajari dulu, baru ditetapin sebagai lokasi”.(wawancara 26 Oktober 2014).

Dalam pelaksanaannya program ini terbagi menjadi dua yaitu Coffee Morning Goes to School yang diadakan langsung di sekolah-sekolah pilihan dan Coffee Morning Goes to Campus yang dilaksanakan langsung dari kampuskampus terpilih di wilayah kota Bengkulu, hal ini disampaikan oleh Misdawati sebagai Kepala Sub. Seksi Pro 2 LPP RRI Bengkulu:

"Untuk pelaksanaan program ini, itu ada dua jenis ya mas.. ada Coffee Morning Goes to School yang disiarkan langsung dari sekolah-sekolah pilihan dan Coffee Morning Goes to Campus disiarkan langsung dari kampus-kampus, nah karena di Bengkulu lebih banyak sekolah dari pada kampus, jadi frekuensi untuk ke sekolah itu lebih banyak".(wawancara 23 Oktober 2014).

Rizki Nopita Handayani Hasan sebagai Pengarah Acara Program Coffee Morning menyatakan mengingat segmen masyarakat pendengar Pro 2 adalah remaja dan anak muda, kemudian dirancang pelaksanaan khusus untuk program ini dengan format edutaiment yaitu menggabungkan antara hiburan dan informasi, pendidikan, ajakan dan sosialisasi:

"Karena tadi kan, pro 2 ini radio yang ditujukan buat anak remaja dan muda, jadi kita memang harus bener-bener usahain penyajiannya bisa diterima sama segment pendengarnya kita. Kan inti dari program ini sebenernya adalah dialog interaktifnya, nah demi mencapai tujuan untuk memastikan pendengar kita tertarik kita padukan informasi dan pendidikannya itu sama hiburan berupa pentas seni, disajikan dengan bahasa ringan yang mudah dipahami, kita juga hadirkan doorprize buat keep attract our audience attention".(wawancara 26 Oktober 2014).

Rizki Nopita Handayani Hasan sebagai Pengarah Acara Program Coffee Morning menambahkan, program ini dilaksanakan dalam durasi dua kali 60 menit.Satu kali 60 menit pertama adalah pentas seni, yang dirancang khusus untuk menjadi ajang penampilan bakat dan minat siswa/mahasiswa dari sekolah/kampus tempat pelaksanaan acara serta wadah promosi bagi sekolah/kampus. Sedangkan dalam satu kali 60 menit ke dua adalah dialog interaktif bersama narasumber berkompeten membahas suatu tema, dimana masyarakat pendengar bisa berpartisipasi aktif secara langsung untuk bertanya jawab dengan narasumber serta memberi kritik dan saran:

"Jadi durasinya itu 2x60 menit mas dibagi menjadi 2 segmen. $1 x 60$ menit pertama, itu adalah segment pentas seni, di segmen ini kita memberikan wadah penyaluran minat bakat dan promosi buat sekolah ato kampus yang jadi lokasi pelaksanaan.Nah pentas seninya kita yang tentuin, harus sesuai dengan tema yang kita angkat. Jadi misalnya, kalo temanya pemilih pemula kan, jadi kita minta sama siswa/mahasiswa yang jadi pengisi acara pentas seni untuk memilih lagu, atau menciptakan karya yang berhubungan dengan tema pemilu gitu,... Abis itu kan di 1x60 menit ke dua itulah inti dari acara ini, diaog interaktif tentang tema bersama narasumber yang 
berkompeten, nah buat ngejaga supayapendengar atau pun audiens nya kita keep attentions kita juga tetep hadirkan penampilan seni dari siswa/mahasiswanya plus juga sama doorprize di akhir. Di segment ke dua ini, kita juga kasih kesempatan buat pendengar atau audiensnya untuk berinteraksi langsung bersama narasumber, kasih kritik saran atau mau tanya jawab juga boleh”.(wawancara 26 Oktober 2014).

Karena ini merupakan program yang disiarkan secara langsung, maka persiapan yang teliti dengan mempelajari segala aspek yang dibutuhkan dan rencana yang terukur, terstruktur amatlah penting untuk memastikan program berjalan dengan baik, hal ini ditekankan oleh Vidya Nuria sebagai Stage Manager Program Coffee Morning:

"Iya.. jadikan karena ini adalah siaran langsung, jadinya semua itu harus perfect, belom lagiini melibatkan pihak luar, maksudnya yang ngisi acara kan bukan dari kita RRI, terus dilaksanakannya juga langsung di sekolah ato kampus, jadi gak boleh ada kesalahan karena ini berhubungan dengan nama baik kita pro 2, RRI dan lokasi tempat kita ngadain acara ini juga. Makanya semuanya harus disiapin secara detail muali dari materi, pengisi acara, lokasi, teknik, pembawa acara, semua semua, harus satu pemahaman, satu tujuan, satu tindakan.." (wawancara 24 Oktober 2014).

Rizki Nopita Handayani Hasan sebagai Pengarah Acara Program Coffee Morning menyatakan untuk menghindarkan kesalahan sekecil apapun perlu adanya persiapan tindakan antisipatif untuk setiap kejadian yang tidak diinginkan. Dilakukan seleksi ketat dalam hal pengisi acara, materi acara dan segala sesuatu yang berhubungan dengan pelaksanaan program ini:

"Buat mastiin semuanya perfect semua kita perhatiin detail, terus juga kita harus siap dengan segala kemungkinan yang gak diinginin kan. Mangkanya kita bener-bener ketat milih pengisi acara, materinya kita pastiin banget, terus kita drill semua pengisi acara untuk serius, supaya mereka benerbener paham ini acara live bukan sekedar ecek-ecek. Karena kita kan radio yah... semua cuma bersumber dari suara, vakum 1 detik aja itu dah gak boleh apa lagi kalo sampek suaranya nggak jelas, yang ngisi nyanyinya jelek, ato pusisinya nggak nyambung, alat teknik mic nya gak nyala misalnya, pokoknya semua harus bener gak boleh ada yang salah, kalo pun nanti ada juga yang gak bener ya itu gak bisa dihindarin, cuma yang perlu itu kitanya harus selalu siap". (wawancara 26 Oktober 2014).

\section{- Memiliki Kerangka Hukum dan} Lembaga

Bapak Deva P. Musri sebagai Kepala Seksi Siaran LPP RRI Bengkulu dalam wawancara pada tanggal 25 Oktober 2014, menyebutkan bahwa RRI sebagai media massa milik Negara, dalam menjalankan visi dan misi berlandaskan pada, maka diketahui pelaksanaan program acara Coffee Morning pro 2 LPP RRI Bengkulu didasari oleh yaitu UU no 32 tahun 2002 tentang Penyiaran, PP 11 tahun 2005 tentang Lembaga Penyiaran Publik, serta PP 12 tahun 2005, SK Dirut, Standar Operasional Prosedur RRI, dan Kode Etik RRI.

Hal ini juga dikuatkan oleh ibu Misdawati selaku Kepala Sub. Seksi Pro 2 dalam wawancara pada 23 Oktober 2014, beliau menyebutkan Pro 2 sebagai bagian dari RRI dalam pelaksaan setiap program acara berpedoman pada kode etik dan 
standar operasional prosedur, begitu juga dengan pelaksanaan program acara Coffee Morning.

Bapak Deva Musri menambahkan bahwa yang dimaksud dengan kode etik RRI adalah prinsip kerja RRI yang menjadi kerangka gerak yang dituangkan dalam visi dan misi RRI. Sementara standar operasional prosedur adalah pedomandan nilai-nilai standar penyiaran, antara lain bersifat independet dan netral, memihak pada kebenaran, memberi pemahaman, mengurangi ketidakpastian, berpedoman pada pancasila, UUD 1945 dan kebenaran, serta peraturan yang lainnya, harus memihak hanya kepada kepentingan Negara Kesatuan Republik Indonesia, dan harus menjaga persatuan, kesatuan dan Kedaulatan NKRI.

Masih menurut bapak Deva P. Musri, dalam merancang dan melaksanakan sebuah program siaran RRI juga harus mengikuti pedoman dan aturan yang diberikan oleh Komisi Penyiaran Indonesia, sebagai lembaga yang akan mengawasi setiap produk yang behubungan dengan dunia penyiaran.

Ibu misdawati mejelaskan, bentuk pelaksanaan dari kerangka hukum dan kerangka kerja RRI tesebut, RRI selalu mengedepankan pemilihan tema, narasumber, materi, hiburan, pendidikan, sosialisai yang bermanfaat dan behubungan dengan hajat orang banyak.

Dalam pelaksanaan program Coffee Morning di Pro 2 kode etik dan standar operasional prosedur tersebut diwujudkan dalam pemilihan tema, nara sumber, dan pelaksanaan pluralisme dengan mengakomodir kelompok minoritas seperti kelompok disabilitas.

Hal ini juga dikuatkan oleh pernyataan ibu Misdawati tentang pentingnya netralitas dan independensi.Lebih lanjut Rizki Nopita H.H, selaku pengarah acara program Coffee Morning juga menekankan pentingnya berpedoman pada kode etik dan standar operasional prosedur dalam setiap tahapan pelaksanaan program tersebut, mulai dari pemilihan tema, narasumber, pengisi acara, audiens, dsb.

Undang-undang No 32 Tentang Penyiaran, yang secara umum undangundang ini menjelaskan bahwa siaran yang dipancarkan dan diterima secara bersamaan, serentak dan bebas memiliki pengaruh yang besar dalam pembentukan pendapat, sikap prilaku khalayak, maka penyelenggaraan penyiaran wajib bertanggung jawab dalam menjaga nilai moral, tata susila, budaya, keperibadian dan kesatuan bangsa yang berlandaskan pancasila.

Lembaga peyiaran merupakan media komonikasi massa yang mempunyai peranan penting dalam kehidupan sosial, budaya, politik dan ekonomi, memiliki kebebasan dan tanggung jawab dalam menjalankan fungsinya sebagai media informasi pendidikan, hiburan serta control dan perekat sosial.

Selanjutnya dalam UU ini yang dimaksud dengan siaran adalah: "pesan atau rangkaian pesan dalam bentuk suara, gambar, atausuara dan gambar, atau yang berbentuk grafis, karakter baik yang bersifat interaktif maupun tidak, yang dapat diterima melalui perangkat penerima siaran“. Adapun fungsi penyiaran sebagai kegiatan komunikasi massa adalah sebagai media informasi pendidikan, hiburan yang sehat, kontrol dan perekat sosial yang diarahkan untuk menjujung tinggi pelaksanaan Pancasila dan UUD 45, menjaga dan meningkatkan moralitas dan nilai agama serta jati diri bangsa, meningkatkan kualitas SDM dan menjaga dan mempererat persatuan dan kesatuan bangsa. Meninmgkatkan kesadaran ketaatan hukum dan disiplin nasional, menyalurkan pendapat umum, serta mendorong peran aktif masyarakat dalam pembangunan nasional dan daerah serta melestarikan lingkungan hidup. Mencegah monopoli kepemilikan dan mendukung persaingan sehat di bidang penyiaran. Mendorong 
peningkatan kemampuan perekonomian rakyat, mewujudkan pemerataan dan memperkuat daya saing bangsa dalam era glbalisasi. Memberikan informasi yang benar, seimbang, dan bertanggung jawab, serta memajukan kebidayaan nasional.

Adapun Standar Operasional RRI dalam penyelenggaraan siaran, antara lain:

1. Siaran bersifat independet dan netral

2. Siaran harus memihak pada kebenaran

3. Siaran memberi pemahaman

4. Siaran mengurangi ketidakpastian

5. Siaran berpedoman pada pancasila, UUD 1945 dan kebenaran, serta peraturan yang lainnya.

6. Siaran harus memihak hanya kepada kepentingan Negara Kesatuan Republik Indonesia

7. Siaran harus menjaga persatuan, kesatuan dan Kedaulatan NKRI

Sementara yang dimaksud dengan

Kode Etik RRI, merupakan prinsip kerja dari Lembaga Penyiaran Publik dimana:

1. LPP adalah lembaga penyiaran untuk semua warga Negara

2. Siarannya harus menjangkau seluruh wilayah Negara

3. Siarannya harus merefleksikan keberagaman

4. Siarannya harus berbeda dengan lembaga penyiaran lainnya

5. LPP harus menegakkan independensi dan netralitas

6. Siarannya harus bervariasi dan berkualitas tinggi

7. Menjadi flag carrier dari bangsa Indonesia

8. Mencerminkan identitas bangsa

9. Perekat dan pemersatu bangsa

Dari jawaban para narasumber di atas dapat diketahui bahwa RRI pada umumnya, dan pelaksanaan program Coffee Morning di Pro 2 LPP RRI Bengkulu memiliki kerangka hukum dan lembaga yang jelas yang menjadi landasan gerak mereka, yang menjadikan mereka selalu berusaha memenuhi tanggung jawab sosial mereka terhadap masyarakat pendengarnya.

\section{Memenuhi Kewajiban Standar Tinggi atau Profesional tentang Keinformasian, Kebenaran, Ketepatan, Objektivitas, dan Keseimbangan}

Menjawab pertanyaan ini, Bapak Deva P. Musri sebagai Kepala Seksi Siaran LPP RRI Bengkulu dalam wawancara pada tanggal 25 Oktober 2014menjelaskan, sebagaimana tertuang dalam kode etik dan standar operasional prosedur RRI, dalam mewujudkan standar tinggi atau profesionalisme keinformasian, yang benar, tepat, objektif dan seimbang, RRI umumnya, dan dalam pelaksanaan program Coffee Morning Pro 2.

Rizki Nopita H. H. selaku pengarah acara program Coffee Morningmenjawab untuk memenuhi kewajibanstandar tinggi atau profesionalisme keinformasian, yang benar, tepat, objektif dan seimbang pada pelaksanaan program Coffee Morning dicerminkan dalam pemilihan tema, penentuan narasumber, pesiapan yang matang dan pelaksanaan yang menghasilkan produk siaran yang berkualitas.

Bapak Deva menambahkan bahwa dari segi penetapan narasumber, ada beberapa faktor yang kemudian harus diperhatikan, antara lain, narasumber harus berkompeten, artinya terlibat dan merasakan langsung, sangat memahami tema yang dibicarakan sehingga informasi yang disampaikan bisa diakui kebenarannya karena berasal dari orang yang benar dan tepat.

Masih menurut Bapak Deva, Jumlah narasumber yang dihadirkan minimal 2 orang dan maksimal 4 orang yang berbeda pendapat atau memiliki latar belakang yang berbeda untuk mendapatkan keberagaman informasi, sehingga informasinya seimbang dan objektif. Jika narasumber hanya satu orang maka hanya aka nada satu sudut pandang saja, yang akan berakibat pada kesenjangan informasi. Jika narasumber lebih dari 4, akan sulit memfokuskan 
pembicaraan, yang akan mengaibatkan pembicaraan menjadi mengambang dan mubazir.

Rizki Nopita H. H. selaku pengarah acara program Coffee Morning mencontohkan, apabila tema yang diangkat adalah 'Pemilih Pemula' kemudian dihadirkan beberapa narasumber, antara lain, yang pertama dari perwakilan siswa sebagai perwakilan dari pemilih pemula yang akan memberi gambaran pengeratahuan dan kesiapan mereka tentang pemilihan umum, dari perwakilan pihak sekolah sebagai Pembina para siswa wakil dari para wali dan orang tua yang akan memberikan gambaran bagaimana cara mereka memberikan bimbingan kepada para pemilih pemula, serta perwakilan dari KPU Kota Bengkulu yang akan memberikan sosialisasi, pendidikan, ajakan, dan pencerahan tentang pemilih pemula dan pemilihan umum itu sendiri. Dengan begitu akan di dapatkan 3 sudut pandang yang berbeda sehingga terciptakan keseimbangan dan keobjektifan informasi.

Dengan kata lain, pemenuhan kewajiban akan standar yang tinggi atau profesional tentang keinformasian, kebenaran, ketepatan, objektivitas, dan keseimbangan telah dilakukan dalam pelaksanaan program acara Coffee Morning di Pro 2 Bengkulu dilihat dari proses pemilihan narasumber yang dilakukan dengan sangat teliti dengan mengutamakan kompetensi dan keberimbangan informasinya.

2. Menghindari Segala Sesuatu yang Mungkin Menimbulkan Kejahatan, Kerusakan atau Ketidaktertiban Umum atau Penghinaan terhadap Minoritas Etnik atau Agama

Untuk menghindari segala sesuatu yang mungkin menimbulkan kejahatan, kerusakan atau ketidaktertiban umum atau penghinaan terhadap minoritas etnik atau agama, dijelaskan oleh Bapak Deva P. Musri sebagai Kepala Seksi Siaran LPP RRI Bengkulu dalam wawancara pada tanggal 25 Oktober 2014 bahwa RRI sangat berhati-hati dalam hal segala sesuatu yang bersifat SARA, karena tema tersebut sangat rentan memicu perpecahan, karenanya RRI lebih memilih untuk menghadirkan tema lain yang membangun. Dan jika pun tema SARA harus dihadirkan, karena mungkin terjadi keresahan di masyarakat terkait sesuatu yang berhubungan dengan tema SARA, maka RRI akan bertindak sebagai penghubung antara pihak yang berseteru untuk menjadikan permasalahan menemukan titik temu dan membantu meredam konflik dalam bentuk dialog, sosialisai dan pendekatan simpatik.

Misdawati sebagai Kepala Sub. Seksi Pro 2 LPP RRI Bengkulu: Wawancara 23 Oktober 2014menyebutkan, isu SARA adalah isu yang paling dihindari untuk dihadirkan karena dapat memicu reaksi langsung dari pendengar. Karenanya RRI khususnya Pro 2 dalam pelaksanaan program Coffee Morning sebisa mungkin menghindari isu SARA demi menjamin keamanan dan ketertiban.

Dalam pemilihan setiap tema dan narasumber program Coffee Morning benarbenar diseleksi dengan mempertimbangan asas manfaat, dan karena isu SARA dinilai rentan kepada hal yang bisa memicu reaksi negatif, karena pada program Coffee Morning isu SARA tidak diangkat, demikian disebutkan oleh Vidya Nuria sebagai Stage Manager Program Coffee Morning: wawancara 24 Oktober 2014.

Pentingnya untuk tidak memancing perpecahan dan reaksi negatif dari pendengar membuat pemilihan tema dan nara sumber sangat ditekankan dalam pelaksanaan program Coffee Morning di Pro 2 LPP RRI Bengkulu. Dengan kata lain, isu tetang SARA tidak akan dihadirkan kecuali jika isu tersebut menjadi alasan sebuah perpecahan. Jika keadaannya demikian maka hal itu akan menjadi kewajiban bagi RRI untuk mengangkat tema SARA yang meresahkan kemudian menjadi penengah, untuk menyatukan 
beberapa pihak sehingga bisa saling bertukar fikiran dalam bentuk dialog yang bersahabat demi kepentingan pencerahan.

\section{Bersifat Plural dan Mencerminkan} Kebhinekaan Masyarakatnya, dengan Memberikan Kesempatan yang Sama untuk Mengungkapkan Berbagai Sudut Pandang dan Hak untuk Menjawab

Menjawab pertanyaan tentang bersifat plural dan mencerminkan kebhinekaan masyarakatnya, Bapak Deva P. Musri sebagai Kepala Seksi Siaran LPP RRI Bengkulu dalam wawancara pada tanggal 25 Oktober 2014menyebutkan Salah satu fungsi RRI adalah untuk merefleksikan keberagaman dalam setiap program acaranya. RRI Bengkulu sudah mencoba mengakomodir kelompok minoritas baik dari segi budaya, agama dan komunitas. Seperti program Minang maimbau untuk komunitas warga Minang, program Horas Tapianauli untuk komunitas warga Sumatera Utara, Senandung Bumi Raflesia untuk komunitas warga Bengkulu, program Kelong-kelong Sulawesi Selatan untuk warga Sulawesi Selatan, Program acara mimbar Protestan, Mimbar Khatolik, Saydul Ayyam, program Suara Kampus, Dunia Wanita, Hello Prajurit dan masih banyak lagi.

Misdawati sebagai Kepala Sub. Seksi Pro 2 LPP RRI Bengkulu: Wawancara $23 \quad$ Oktober 2014menambahkan, di Pro 2 pun sudah dihadirkan bentuk keberagaman dengan menghadirkan program-program yang mengakomodir komunitas anak muda seperti program Pro Kampus untuk anak kampus, PRO INDI untuk komunitas musisi lokal Bengkulu, program PRO \& COM yang merupakan program dengan segemen anak muda dengan komunitaskomunitas sosialnya seperti komunitas motor, komunitas hobi dan sebagainya, program OBSI untuk komunitas anak muda berprestasi, para pengusaha muda, program Get Asian Songs yang merupakan program untuk komunitas anak muda pencinta lagulagu Korea, Cina dan Jepang.Program Rock Fiesta untuk para pencinta musik aliran rock, program Qalbu Plus untuk siaraman rohani Islan, dan masih banyak program lain yang dirancang untuk mengakomodir kelompok di masyarakat dan memberikan kesempatan yang sama untuk menggunakan RRI sebagai media komunikasi.

Khusus untuk pelaksanaan program Coffee Morning di Pro 2 Bengkulu Rizki Nopita Handayani Hasan sebagai Pengarah Acara Program Coffee Morning: wawancara 26 Oktober 2014mengungkapkan bahwa, juga diakomodir kelompok minoritas seperti kelompok disabilitas. Program ini pernah mengangkat tema 'Disabilitas Memilih’ yang dilaksanakan di SLB N Kota Bengkulu pada bulan Maret 2014.Dengan menghadirkan narasumber, dan para pengisi acara dari perwakilan yang juga berasal dari perwakilan disabilitas.

Sementara dalam hal untuk mengakomodir hak mengungkapkan pandangan dan bertanya jawab di RRI, RRI pun memberikan ruang yang sangat luas untuk masyarakat berpartisipasi aktif dalam setiap program acaranya melalui line telpon dan SMS sebagaimana diungkapkan oleh Bapak Deva P. Musri selaku Kepala Seksi Siaran LPP RRI Bengkulu: wawancara 25 Oktober 2014.

Begitu juga dengan pelaksanaan program Coffee Morning di Pro 2 Bengkulu, masyarakat juga diberikan yangbesar untuk ikut berpartisipasi aktif. Pro 2 melalui program ini, memberikan kesempatan yang sama untuk mengungkapkan berbagai sudut pandang dan hak untuk menjawab, Rizki Nopita Handayani Hasan sebagai Pengarah Acara Program Coffee Morning: wawancara 26 Oktober 2014menyebutkan program ini juga mengakomodir tema yangberkaitan dengan kelompok minoritas seperti disabilitas. Narasumber dari kelompok minoritas atau disabilitas pun dimungkinkan selama orang yang akan 
dijadikan narasumber

berkompeten.

Febby Prapita Sari, selaku pembawa acara dialog di sesi ke dua program Coffee Morning Pro 2 menyebutkan Pro 2 pernah mengakat tema tentang 'Disabilitas Memilih', tema yang mengakomodir kelompok disabilitas, salah satu narasumber kal itu adalah salah seorang penyandang disabilitas, dengan kata lain jika seseorang itu kompeten di bidangnya, maka dia layak menjadi narasumber.

Bapak Deva menjelaskan di dalam setiap pelaksanaan program acara di RRI, masyarakat diundang dan diberikan kebebasan serta kesempatan untuk berpartisipasi aktif memberikan pendapat, bertanya, menjawab, mendapatkan informasi, hiburan dan memberi kritik dan saran melalui line telpon dan SMS.

Begitu juga dengan pelaksanaan program Coffee Morning di Pro 2 Bengkulu seperti dijelaskan oleh Vidya Nurina selaku Stage Manager Program Coffee Morning Pro 2. Audiens diberikan hak untuk berpatisipasi dalam memberikan pendapat, bertanya dan mendapatkan jawaban akan sebuah permasalahan yang dihadapi sesuai dengan tema yang diangkat, di dalam program ini, pada sesi ke 2 saat dialog intersaktif dilaksanakan, audiens diberikan kesempatan untuk bertanya langsung kepada narasumber.

Namun RRI juga memberikan aturan yang jelas dalam hal keterlibatan masyarakat dalam setiap program siarannya. Segala bentuk partisipasi masyarakat akan disalurkan selagi pertanyaan, pernyataan, kritik dan saran tersebut tidak bersifat provokasi yang bisa menyebabkan perpecahan. Untuk memastikan hal tersebut, pembawa acara diizinkan melakukan intervensi, menengahi, memotong atau bahkan menghentikan jika dirasa sudah mulai mengarah pada tindakan yang mengundang kerusakan ketertiban dan kenyamanan. Untuk melihat lebih jelas rangkaian pelaksanaan program Coffee
Morning, telah dilampirkan contoh rundown dan daftar lokasi, tema, dan narasumber pada halaman lampiran.

\section{Masyarakat Dapat Mengharapkan Standar Prestasi yang Tinggi dan Intervensi Dapat Dibenarkan untuk Mengamankan Kepentingan Umum}

Standar prestasi yang tinggi bagi RRI adalah ketika produk siaran yang dihasilkan bermanfaat, mendidik, dan mampu membangun pola pikir positif bahkan mendorong pada terciptanya tindakan yang positif dari masyarakat pendengar, demikin dijelaskan oleh Bapak Deva P. Musri selaku Kepala Seksi Siaran LPP RRI Bengkulu: wawancara 25 Oktober 2014.

Ia menambahkan, penting bagi RRI untuk tetap netral dan independen, tetapi jika sebagai contoh isu SARA muncul dan menyebabkan keresahan, maka intervensi positif semisal pengeditan berita, atau informasi yang mungkin bisa menambah keruh suasana akan dibenarkan.

Menurut Bapak Deva P. Musri selaku Kepala Seksi Siaran LPP RRI Bengkulu: wawancara 25 Oktober 2014 sebuah program acara dikatakan berhasil jika mampu memberikan pengaruh positif kepada masyarakat pendengar baik itu secara pasif maupun aktif. Untuk mencapai keberhasilan tersebut sangat penting dilakukan persiapan, pengkajian, survey dan kematangan konsep sebelum sebuah program dilaksanakan, sehingga program yang dibuat bukan hanya sekedar menambah panjang daftar isi saja.

Vidya Nurina selaku Stage Manager

Program Coffee Morning Pro 2 menjelaskan, setiap akan melaksanakan program coffee morning, tim akan terlebih dahulu terlibat dalam rapat produksi yang akan membahas secara rinci tentang rencana pelaksanaan, bagaimana pelaksanaan, dan sebagainya. Setelah itu akan dilakukan survey, pendekatan persuasive kepada semua pihak yang berhubungan dengan rencana pelaksanaan, kemudian hasilnya didiskusikan kembali 
dalam rapat produksi lanjutan, barulah setelah semua hal yang dirasa perlu siap dilakukan pengkonsepan acara, dst. Dengan demikian program acara ini bisa berjalan dengan baik dan diharapkan bisa sukses serta bisa memberikan manfaat.

Mempelajari dengan baik tema, narasumber, kemudian membuat perencanaan yang baik, memastikan pelaksanaan terkaji dan terkonsep merupakan salah satu cara agar pelaksanaan program Coffee Morningsukses dan dapat memberikan manfaat bagi masyarakat.

\section{Bertanggung Jawab terhadap Masyarakat dan Kepada Majikan Serta Pasar}

Ibu Misdawati sebagai Kepala Sub. Seksi Pro 2 LPP RRI Bengkulu: Wawancara 23 Oktober 2014 menyebutkan, untuk menjaga program ini tetap berjalan di koridornya, disetiap pelaksanaan coffee morning diundang dan dihadirkan perwakilan dari komisi penyiaran Indonesia daerah provinsi Bengkulu. Yang akan bertindak sebagai pengawas, penasehat, pemerhati dalam memberikan kritik dan saran demi tercapainya perbaikan di masa yang akan datang.

Vidya Nurina sebagai Stage Manager Program Coffee Morning: wawancara $24 \quad$ Oktober 2014 menambahkan, Setelah berbagai persiapan dan seleksi yang dilakukan, kemudian pengarah acara selaku penanggung jawab pelaksanaan program acara dilapangan, akan menyusun rundown. Rundown tersebut akan menjadi kerangka kerja dalam pelaksanaan siaran langsung program acara coffee morning, yang berisikan urutan detail mata kegiatan lengkap dengan nama pengisi acara, materi, nama narasumber, waktu, ucapan pembawa acara, daftar pertanyaan , dsb. Hal ini diperlukan untuk memastikan terjadi kesamaan pemahaman visi dan misi, akan waktu dan tujuan dari pelaksanaan program bagi setiap pihak yang terlibat.

Harry Handika sebagai Pembawa acara: wawancara 24 oktober 2014 menyebutkan rundown merupakan koridor bagi para pengisi acara, teknisi, pemateri, pemandu acara akan berjalan sesuai jadwal dan urutan kegiatan dipimpin oleh stage manager selaku pemimpin pelaksanaan, sementara pengarah acara akan menjadi pengawas pelaksanaan dan menyiapkan segala bentuk tindakan yang diperlukan dalam mengantisipasi hal-hal yang tidak diinginkan.

Febby Prapita Sari, sebagai Pembawa Acara: wawancara 23 Oktober 2014 bmenambahkan, Berdasarkan jawaban para nara sumber dapat disimpulkan adanya kerangka kerja yang satu dalam bentuk rundown, menjadikan pelaksanaan program Coffee Morning Pro 2 LPP RRI Bengkulu terjaga kualitasnya, bertanggung jawab, terstruktur, berurutan dan terukur.

Sementara untuk memastikan pelaksanaannya memenuhi tanggung jawab sosial terhadap pendengar dan audiensnya Bapak Deva P. Musri selaku Kepala Seksi Siaran LPP RRI Bengkulu: wawancara 25 Oktober 2014 menyatakan RRI melakukan kerjasama dengan Komisi Penyiaran Indonesia Daerah Provinsi Bengkulu. Sebagaimana disebutkan dalam UU No 32 Tentang Penyiaran, dalam pelaksanaan tugas siarannya RRI akan selalu beriringan dengan Komisi Penyiaran Indonesia (KPI). KPI merupakan wujud peran serta masyarakat dalam bidang penyiaran.

Masih menurut Bapak Deva, KPI menetapkan standar program siaran, menyusun peraturan dan pedoman perilaku penyiaran dan mengawasi pelaksanaan peraturan dan pedoman tersebut. Oleh karena itu, dalam setiap pelaksanaan program Coffee Morning di Pro 2 LPP RRI Bengkulu, KPI Selalu dilibatkan untuk menjaga agar program ini tetap berjalan sesuai koridor kode etik, standar operasional prosedur, dan kerangka hukum dan lembaga RRI, serta aturan dan pedoman penyiaran.

Rizki Nopita Handayani Hasan sebagai Pengarah Acara Program Coffee 
Morning: wawancara 26 Oktober 2014, menyebutkan bahwadisetiap pelaksanaan program Coffee Morning juga diundang dan dihadirkan pihak komisi penyiaran Indonesia daerah provinsi Bengkulu, yang menjadi pengawas, pemerhati, pemberi kritik dan saran atau bahkan jika dianggap melanggar program acara tersebut dapat dihentikan, dihapuskan lebih tegas lagi jika dianggap peril KPI akan memberikan rekomendasi untuk memberikan hukuman pada RRI jika dianggap melanggar berupa pemecatan anggota Direksi Pimpinan RRI kepada Presiden.

\section{PENUTUP}

\section{Kesimpulan}

Berdasarkan hasil penelitian, simpulan dalam penelitian ini adalah:

1. Program ini dilakukan dengan berlandaskan kerangka hukum dan lembaga yang jelas yaitu UU no 32 tahun 2002 tentang Penyiaran, PP 11 tahun 2005 tentang Lembaga Penyiaran Publik, serta PP 12 tahun 2005, SK Dirut, Kode Etik dan Standar Operasional Prosedur serta berpedoman pada aturan dari Komisi Penyiaran Indonesia sebagai tanggung jawab kepada masyarakat.

2. Program ini telah memenuhi kewajiban memenuhi standar yang tinggi atau profesional tentang keinformasian, kebenaran, ketepatan, objektivitas, dan keseimbangan. Hal ini terlihat dari bagaimana pemilihan tema dan penentuan nara sumber yang berkompeten, pengisi acara dan lokasi. Namun tema yang diangkat belum sepenuhnya menyentuh kebutuhan segmen pendengarnya.

3. Pelaksanaan program ini telah menghindari segala sesuatu yang mungkin menimbulkan kejahatan, kerusakan atau ketidaktertiban umum atau penghinaan terhadap minoritas etnik atau agama, dengan menghindari isu SARA, namun jika isu SARA itu yang menjadi penyebab keresahan, maka menjadi kewajiban RRI dalam hal menjadi media yang bisa menjadi wadah dialog yang akan memberikan pencerahan dengan menghadirkan narasumber yang berkompeten.

4. Dalam pelaksanaannya program ini telah berupaya bersifat plural dan mencerminkan kebhinekaan masyarakatnya, dengan memberikan kesempatan yang sama untuk mengungkapkan berbagai sudut pandang dan hak untuk menjawab, dengan memberikan porsi yang sama bagi kelompok minoritas dan kepada siapapun untuk memberikan pendapat, menyampaikan kritik dan saran serta bertanya jawab dalam dialog yang bersahabat.

5. Program ini menetapkan standar prestasi yang tinggi dan intervensi dapat dibenarkan untuk mengamankan kepentingan umum, berupa pemastian bahwa program berkualitas, berjalan dengan sukses, mengangkat tema yang bermanfaat sehingga diharapkan dapat mengajak, mengayom, membimbing, mendidik dan lebih jauh menciptakan reaksi berupa perubahan tindakan positif baik pasif maupun aktif. Bentuk penyajian progran ini sudah berhasil menggugah minat segemen pendengarnya, namun dirasa masih perlu mendapatkan kajian tentang penggunaan bahasa retorika dalam penyampaian pesan oleh pembawa acara sehingga lebih bisa mengangkat dan mengikat emosi pendengar.

7. Pelaksanaan program ini telah bertanggung jawab terhadap masyarakat pendengarnya dan juga kepada majikan serta pasar. Hal ini dapat terlihat dari bagaimana program ini direncanakan sampai dengan pelaksanaannya dengan standar keberhasilan yang tinggi, dilaksanakan dengan terstruktur dan terukur. Sedangkan untuk menjaga agar program ini tetap pada koridornya dan 
bertanggung jawab sosial kepada masyarakat dilibatkan juga Komisi Penyiaran Indonesia Provinsi Bengkulu yangbertindak sebagai pengawas, pembimbing yang akan memberikan kritik dan saran demi kemajuan program kedepan.

\section{Saran}

Perencanaan dan pelaksanaan program acara coffee morning sudah menunjukkan tanggung jawab sosial kepada massa pendengar dan audiensnya, namun tetap penulis memiliki beberapa saran untuk dipertimbangkan dalam rangka perbaikan atau memperkaya program ini kedepannya, adapun saran penulis untuk pelaksanaan program coffee morning antara lain:

1. Menurut penulis, cara penyampaian dalam hal ini bahasa yang digunakan pembawa acara belum bisa benar-benar mempengaruhi pendengar atau audiens. Akan lebih baik jika diakhir acara pembawa acara bisa menyimpulkan dan mengajak pendengar/audiens menggunakan bahasa yang membangun, menggugah, dan mempengaruhi, seperti bahasa yang digunakan dalam pidato soekarno misalnya.

2. Mengangkat tema yang lebih dekat dengan kehidupan dan kebutuhan pendengar/audiens. Sebagi contoh tema tentang minat dan bakat, memulai wirausaha, dsb.

\section{DAFTAR PUSTAKA}

\section{Buku}

Bajari, Atwar. (2008). "Media Massa dan Tanggung Jawab kepada Publik”. Jakarta: Reneka Cipta.

Fachry. (2013). “Teori Pers Tanggung Jawab Sosial (Social Responsibility)”. Surabaya: Masmedia Buana Pustaka.
Indra Astuti, Santi. (2010). "Jurmalistik Radio (Teori dan Praktek)”. Jakarta: Simbiosa Rekatama Media.

\section{Perundang-undangan}

Undang-undang Republik Indonesia nomor 32 Tahun 2002 Tentang Penyiaran

PP No 11 Tahun 2005 Tentang Penyelengaraan Penyiaran Lembaga Penyiaran Publik

\section{Referensi (Skripsi, Makalah, Modul)}

Erkuliani, Achadtia. (2014). Profesionalisme Wartawan Televisi dalam Meliput Berita (studi pada wartawan Batu TV). Skripsi S1 Fakultas Ilmu Sosial dan Ilmu Politik Batu (tidak dipublikasikan).

Faiqoh, Elok. (2008). Manajemen Siaran Acara 3B (Belajar Bermain Bersama) di Radio Anak Jogjakarta. Skripsi Program S.1 Fakultas Dakwah Universitas Islam Negri Sunan Kalijaga Yogyakarta (tidak dipublikasikan).

Oktaviarini, Monika. 2006. Tanggung Jawab Televisi Lokal dalam Pelestarian Budaya Lokal: Kasus Banyumas Televisi Citra. Skripsi S.1 Fakultas Ilmu Sosial dan Ilmu Politik Universitas Indonesia (tidak dipublikasikan).

Prapita Sari, Febby. 2007. Pengaruh Isi Siaran, Jenis Musik dan Style Suara Penyiar terhadap Minat Pendengar RRI PRO 2 FM Bengkulu (Studi Kasus Pendengar Program Acara Cyber Zone). Skripsi S.1 Fakultas Ilmu Sosial dan Ilmu Politik Universitas Bengkulu (tidak dipublikasikan).

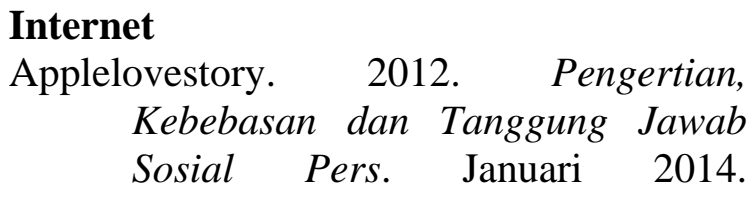


http://applelovestory.wordpress.com /pengertian-kebebasan-dantanggung-jawab-sosial-pers/

Filyamma, Jaka. 2013. Sistem Komunikasi Tanggung Jawab Sosial. Pukul 03.19. Kamis 9 Mei 2013. http://jakafilyamma.blogspot.com/2 013/05/sistem-komunikasitanggung-jawab-sosial.html.

Januar Prathama, Ryanda. 2009. Teori Pers Tanggung Jawab Sosial. Pukul 01.34.8 Juli 2009. http://boyslikegirl324.blogspot.com/ 2009/07/teori-pers-tanggung-jawabsosial.html.

Kurnia Ningtyas, Aini. 2009. Teori Pers Tanggung Jawab Sosial. Pukul 02.12. Rabu 8 Juli 2009. http://nurainikurnianingtyas.blogspo t.com/2009/07/teori-pers-tanggungjawab-sosial.html.

Kusumawardana, Anita. 2010. Teori Empat Pers. Pukul 06.15. Senin, 07 Juni $2010 . \quad$ http://gudangilmublooddy.blogspot.com/2010/06/teori -empat-pers.html.

M. Achmad, Zainal, 2013. Sejarah Perkembangan Radio. 2 Mei 2013. http://zain.staff.ub.ac.id /2013/02/05/perkembangan-danjenis-radio/

Muda, Penulis. 2012. Empat Teori Pers Menurut Para Ahli. Pukul 16.50. Februari 2012. http://suniolathif.blogspot.com/2012 /02/empat-teori-pers-menurut-paraahli.html.
Musa, Angelo. 2011. Karakteristik Radio Siaran. 4 Oktober 2011. http://musa666.wordpress.com/ 2011/10/04/karakteristik-radiosiaran/

Pradita, Dinda. 2009. Teori Pers Tanggung Jawab Sosial.Rabu, 8 Juli 2009. http://dindapradita.blogspot.com/2009/07/teoripers-tanggung-jawab-sosial.html.

Prakosa, Adi. 2009. Teori Normatif Komunikasi Massa. Pukul 03.19.Senin, 5 Oktober 2009 . http://adiprakosa.blogspot.com/2009 $\underline{10 /}$ teorinormatifkomunikasimassa.html.

Rahmawan, Tizar. 2009. Contoh Proposal Penelitian Kualitatif. 9 Desember 2009.

file:///E:/bahan\%20skripsi/CONTO H\%20PROPOSAL\%20PENELITIA N\%20KUALITATIF\%20\%20\%20T izar\%20Rahmawan.html.

Teddy, Pak. 2008. Empat Teori Pers. Pukul 18.49. Jumat, 07 November 2008.http://pakteddy.blogspot.com/2 008/11/teori-teori-pers.html.

Zega, Tian. 2007. Mengenal Jenis Frekwensi Radio Komunikasi dan Cara Kerjanya, 7 Juni 2007. http://tianzega.wordpress.com/2007/ 06/07/mengenal-jenis-frekwensiradio-komunikasi-dan-carakerjanya/. 